\title{
PERFORMANS BURUNG PUYUH (Coturnix-Coturnix Japonica) FASE GROWER YANG DIBERIKAN TEPUNG MANURE HASIL DEGRADASI LARVA LALAT HITAM (H. illucensL.) MENGGANTIKAN TEPUNG IKAN DALAM RANSUM
}

\author{
Yasmira Wenda, H.J. Manangkot*, J. L. P. Saerang, Cherlie L. K. Sarajar
}

Fakultas Peternakan Universitas Sam Ratulangi, Manado. ABSTRAK

\begin{abstract}
ABSTRAK
Penelitian ini bertujuan untuk mengetahui manure hasil degradasi larva lalat hitam menggantikan tepung ikan dalam ransum burung puyuh fase grower. Materi yang digunakan dalam penelitian ini adalah 100 ekor unsexed burung puyuh umur 3 minggu, kadang yang digunakan berukuran $40 \times 40 \times 20 \mathrm{~cm}$. Penempatan burung puyuh dalam setiap unit kandang di lakukan secara acak. Rancangan yang digunakan dalam penelitian ini adalah rancangan acak lengkap (RAL) dengan 4 perlakuan dan 5 ulangan. Tiap ulangan percobaan menggunakan burung puyuh umur 3 minggu dengan perlakuan; R0 $=0 \%$ tepung manure hasil degradasi (MHD); R1 $=4 \%$ tepung $\mathrm{MHD} ; \mathrm{R} 2=8 \%$ tepung MHD; R3 $=12 \%$ tepung MHD. Variabel penelitian terdiri dari konsumsi ransum, pertambahan bobot badan dan efisiensi ransum burung puyuh. Hasil penelitian yang diperoleh menunjukkan perlakuan memberikan penggaruh yang sangat nyata $(\mathrm{P}<0,01)$ terhadap konsumsi ransum. Pertambahan bobot badan dan efinsiensi penggunaan ransum tidak berbeda nyata ( $\mathrm{P}>0,05)$. Kesimpulan penelitian ini adalah tepung MHD sampai level $12 \%$ dapat digunakan dalam ransum burung puyuh menggantikan tepung ikan.
\end{abstract}

Kata kunci : Burung Puyuh, MHD, Tepung ikan

\footnotetext{
*Korespondensi (corresponding aouthor) Email: hmanangkot@gmail.com
}

\author{
ABSTRACT
}

\begin{abstract}
QUAIL (Coturnix-Coturnix Japonica) GROWER PERFORMANCE SUPPLIED WITH MANURE FLOUR DEGRADED BY BLACK FLY LARVAE (H.ILLUCENS L.) TO REPLACE FISH MEAL. This study aims to determine the manure yield of black fly larvae replacing fish meal in the quail feed of the grower phase. The materials used in this study were 100 unsexed quails, 3 weeks old; the dimension of cage was $40 \times 40 \times 20$ $\mathrm{cm}$. The quails were arranged randomly in each unit. The study was realized by using a completely randomized design (CRD) with 4 treatments and 5 replications. The treatments were $\mathrm{R} 0=0 \%$ degraded manure flour (MHD); R1 = 4\% MHD flour; R2 = $8 \%$ MHD flour; R3 $=12 \%$ MHD flour. The research variables consisted of ration consumption, body weight gain and feed efficiency. The results obtained showed that treatments provide a very significant influence $(\mathrm{P}<0.01)$ on ration consumption. Body weight gain and feed efficiency were not significant different $(\mathrm{P}>0.05)$. The conclusion of this study is that MHD flour up to the $12 \%$ level can be used in quail rations replacing fish meal.
\end{abstract}

Keywords: Quail, MHD, Fish meal. 


\section{PENDAHULUAN}

Salah satu program pemerintah dalam pembangunan bidang peternakan ditujukan pada peningkatan populasi dan produksi ternak. Burung puyuh termasuk salah satu jenis ternak dalam kelompok aneka ternak yang lebih di kenal oleh masyarakat peternak di bandingkan dengan jenis aneka ternak laninnya. Beberapa keuntungan memelihara burung puyuh yaitu daur hidupnnya singkat, cepat mencapai dewasa kelamin, produksi telurnnya cukup tinggi, periode penetasan singkat,cara pemeliharaannya sederhana, tidak memerlukan areal yang luas, dan modal relative rendah sehingga dapat dijadikan sebagai usaha keluarga.

Tatalaksana pemberian pakan merupakan salah satu faktor penentu keberhasilan proses produksi di samping faktor penyediaan bibit dan makanan yang berkualitas.

Masalah yang sering dihadapi peternak burung puyuh ialah adanya beberapa bahan makanan penyusun ransum yang sering bersaing dengan kebutuhan manusia maupun kebutuhan ternak yang lain sehingga ketersediaan juga sering mengalami fluktuasi disamping harganya mahal.

Misalnya tepung ikan, semua ternak ungas menggunakan tepung ikan dalam ransum dan harganya sudah semakin mahal berkisar Rp. 12.000/kg. Oleh karena itu salah satu usaha untuk mencari dan meneliti bahan lain yang dapat menggantikan sebagian atau seluruh tepung ikan dalam ransum. Upaya yang dapat dilakukan untuk mengatasi kemungkinan terjadinya fluktuasi ketersediaan tepung ikan di pasaran, bahan makanan tersebut tentunya mempunyai kualitas minimal sama dengan tepung ikan, murah, mudah didapat, tidak bersaing dengan kebutuhan ternak lainnya dan kebutuhan manusia. Manure hasil degradasi (MHD) merupakan hasil biodegradasi larva lalat hitam (H. illucens $L)$. Manure berasal dari feces dan urine ayam broiler umur 2 minggu dan larva umur 8 hari berasal dari lalat hitam, yang dua- duanya (manure dan lalat hitam) berasal dari kandang ayam yang berlokasi di Desa Kembuan Kecamatan Tondano Kabupaten Minahasa. MHD dapat dijadikan bahan pakan pengganti tepung manure baik sebagian maupun keseluruhan karena kandungan proteinnya yang tinggi dan merupakan salah satu bahan pakan alternatif yang mudah didapat, murah, tidak bersaing deangan kebutuhan manusia dan ternak lainnya, memiliki nilai nutrisi yang hampir sama dengan kandungan proteinnya mencapai $51,15 \%$, terdapat enzim-enzim yang dapat membantu proses pertumbuhan ternak puyuh dan memiliki kandungan nutrisi yang layak di jadikan pakan untuk ternak, enzim- enzim yang ada dalam 
tepung MHD yaitu enzim protease, amilase, dan lipase.

Tepung ikan merupakan salah satu bahan makanan sumber protein hewani yang memiliki nilai nutrisi yang hampir sama dengan MHD. Berdasarkan pemikiran di atas maka telah dilakukan penelitian untuk mengetahui penggunaan tepungmanure hasil degradasi larva lalat hitam (Hermetia illucens L)menggantikan tepung ikan sampai $12 \%$ dalam ransum terhadap pertumbuhan burung puyuh fase grower.

\section{MATERI DAN METODE PENELITIAN}

Burung Puyuh yang digunakan dalam percobaan ini berjumlah 100 ekor 'Unsexed"' jenis coturrnix - coturnix japonica yang ber umur satu minggu. Bahan-bahanpakanyang digunakan dalam penelitian adalah jagung kuning, dedak halus, tepung ikan, konsentrat, tepung MHD.

Tabel 1. Komposisi Zat-zat Makanan dari Bahan Penyusun Ransum Percobaan

\begin{tabular}{lcccccc}
\hline $\begin{array}{l}\text { Bahan Makanan } \\
\text { Kkal/kg }\end{array}$ & Protein & lemak & Sk & Ca & P & M.E \\
\hline Jagung kuning *) & 8,80 & $3,902$. & 0 & 0,02 & 0,30 & 3370 \\
Dedak halus *) & 12,0 & 13,0 & 12,0 & 0.12 & 1,5 & 1630 \\
Tepung ikan *) & 60,0 & 9,0 & 1,0 & 5,50 & 2,80 & 3080 \\
Konsentrat **) & 22,0 & 7,0 & 7,0 & 3,2 & 1,0 & 2800 \\
Tepung MHD***) & 51.1 & 52,75 & 2,06 & 9,84 & 3,2 & 2940 \\
\hline
\end{tabular}

Sumber *) NRC (1994)

**) PT. Sinta Prima Feedmill (1982)

***) Hasil Analisa Manangkot (2014)

Tabel 2 . Komposisi Bahan Makanan dan Zat-zat Makanan dari Ransum Percobaa

\begin{tabular}{lcccc}
\hline & \multicolumn{5}{c}{ Jumlah (\%) } \\
\cline { 2 - 5 } Bahan makanan & R0 & R1 & R2 & R3 \\
\hline Jagung Kuning & 45 & 45 & 45 & 45 \\
Dedak Halus & 10 & 10 & 10 & 10 \\
Tepung Ikan & 12 & 8 & 4 & 0 \\
Konsentrat & 33 & 33 & 33 & 33 \\
Tepung MHD & 0 & 4 & 8 & 12 \\
\hline Total & 100 & 100 & 100 & 100 \\
\hline
\end{tabular}


Tabel 3 . Komposisi Zat-zat Makanan Ransum Percobaan

\begin{tabular}{lccll}
\hline Kandungan zat-zat makanan & R0 & R1 & R2 & R3 \\
\hline Protein (\%) & 19,62 & 19,40 & 18,91 & 18,20 \\
Lemak (\%) & 5,48 & 5,55 & 5,62 & 5,69 \\
Serat Kasar (\%) & 5,49 & 5,21 & 4,93 & 4,66 \\
Ca (Kalsium (\%) & 1,74 & 1,91 & 2,08 & 2,20 \\
P (Fosfor) (\%) & 0,54 & 0,06 & 0,79 & 0,89 \\
M .E. Kkal/kg *) & 2934 & 2938 & 2942 & 2947 \\
\hline
\end{tabular}

Ket : *) Dihitung Berdasarkan Pentunjuk Schaible, 1976.

Perlakuan menggunakan ransum yang disusun berdasarkan kebutuhan burung puyuh. Kandang yang digunakan adalah kandang baterai sebanyak 20 unit denganukuran tiap - tiap unitnya 40 x 20 x $20 \mathrm{~cm}$.

Pada setiap unit kandang di tempati 5 ekor burung puyuh, dilengkapi dengan tempat makan serta minum dan alat penerang listrik, Peralatan lain yang digunakan adalah timbangan, peralatan tulis menulis. Ransum perlakuan yang diberikan ada 3 macam dengan perbendaan, perbendaan tingkat penggunaan tepung manure hasil degradasi larva lalat hitam $H$. illucens $L$ Sebagai pengganti tepung ikan sebagai berikut :

$\mathrm{R} 0=$ Ransum yang menggunakan tepung ikan $12 \%$ tanpa menggunakan MHD $\mathrm{R} 1=$ Ransum yang menggunakan tepung ikan 8\% dan Tepung MHD 4\%

$\mathrm{R} 2=$ Ransum yang menggunakan tepung ikan 4\% dan tepung MHD 8\%
R3= Ransum yang menggunakan MHD $12 \%$ tanpa menggunakan tepung ikan.

Rancangan yang digunakan adalah Rancangan Acak Lengkap (RAL) dengan 4 Perlakuan dan 5 Ulangan (Steel dan Torrie, 1994).

\section{Variabel Yang diamati}

Variabel yang diamati dalam penelitian ini meliputi :

1. Konsumsi ransum dapat dihitung berdasarkan rumus (Anggorodi, 1985) Konsumsi Ransum adalah ransum yang diberikan (g/ekor/hari) dikurangi jumlah ransum yang tersisa (g/ekor/hari).

2. Pertambahan berat badan (Sudrajat, 2002). Selisih antara berat badan akhir dan berat badan awal.

3. Efisiensi penggunaan ransum (Rasyaf, 1984).

$\mathrm{EPR}=$

$\underline{\text { Total pertambahan berat badan }(\mathrm{g})}$ Total konsumsi ransum (g) 


\section{HASIL DAN PEMBAHASAN}

\section{Pengaruh Pengunaan Tepung Manure Hasil Degradasi Larva Lalat Hitam Terhadap Konsumsi Ransum}

Hasil pengamatan dan perhitungan rataan konsumsi ransum dari masingmasing perlakuan yang diberikan selama percobaan. Rataan konsumsi ransum per ekor per hari untuk masing-masing perlakuan selama percobaan. Dari Rataan dapat dilihat bahwa peningkatan level tepung manure hasil degradasi (MHD) dalam pakan/ransum burung puyuh.

Hasil analisis ragam menunjukkan bahwa pemberian tepung manure hasil degradasi larva lalat hitam (MHD) pada ransum burung puyuh memberikan pengaruh yang berbeda sangat nyata $(\mathrm{P}<0.01)$ terhadap konsumsi ransum. Hasil uji BNJ menujukkan bahwa konsumsi ransum $\mathrm{R} 0$ berbeda tidak nyata dengan $\mathrm{R} 2$, $\mathrm{R} 3$, tetapi berbeda nyata dengan R1 . Sedangkan R2 berbeda tidak nyata dengan $\mathrm{R} 3$ tetapi berbeda nyata $\mathrm{R} 1$ dan $\mathrm{R} 2$ berbeda tidak nyata dengan R3. Semakin tinggi level penggunaan MHD dalam ransum, semakin tinggi konsumsi ransum. Meningkatnya konsumsi ransum pada perlakuan R1, R2 dan R3 disebabkan karena ransum yang mengandung tepung
MHD mempunyai bentuk partikel yang lebih halus sehingga lebih mudah dikonsumsi. Rataan konsumsi ransum berkisar antara 24,77-24,89 g/ekor/hari Perlakuan yang menggunakan tepung MHD dengan level 4 - 12\% menujukkan rataan konsumsi lebih tinggi dibandingkan dengan ransum kontrol. Sunarno (2004) menyatakan konsumsi ransum burung puyuh umur 21 sampai 55 hari konsumsi ransum sekitar 14-24 g/ekor/hari. Menurut North dan Bell (1990), faktor yang berpengaruhi konsumsi pakan harian pada unggas, kelompok yang berpengaruh dominan adalah suhu lingkungan, berpengaruh bobot badan puyuh harian, pertumbuhan bulu,derajat stress dan aktifitas burung puyuh.

\section{Pengaruh Perlakuan Terhadap Pertambahan Berat Badan Burung Puyuh}

Hasil pengamatan dan perhitugan terhadap rataan pertambahan berat badan per ekor per hari untuk masing-masing perlakuan selama percobaan.

Hasil analisis ragam menunjukkan bahwa pemberian tepung manure hasil degradasi larva lalat hitam pada ransum burung puyuh memberikan pengaruh yang tidak nyata $(\mathrm{P}>0,05)$ terhadap berat badan. 
Tabel 4. Rataan Konsumsi Pakan,Pertambahan Berat Badan, dan Efisiensi Makanan Pakan Selama Penelitian

\begin{tabular}{lcccc}
\hline \multirow{2}{*}{\multicolumn{1}{c}{ Variabel }} & \multicolumn{4}{c}{ Perlakuan } \\
\cline { 2 - 5 } & $\mathrm{R} 0$ & $\mathrm{R} 1$ & $\mathrm{R} 2$ & $\mathrm{R} 3$ \\
\hline Konsumsi pakan $(\mathrm{g})$ & 24,89 & 17,48 & 24,65 & 24,77 \\
Pertambahan berat badan (g) & 6,97 & 6,15 & 7,65 & 5,66 \\
Efisiensi penggunaan ransum & 0,28 & 0,35 & 0,31 & 0,22 \\
\hline
\end{tabular}

Rataan pertambaan berat badan burung puyuh berkisar antara 5,66\% - 6,97\% (Tabel 4). Walaupun secara statistik tidak nyata namun pertambaan berat badan menunjukkan peningkatan dari perlakuan R1, R2, dan R3. Hal ini sejalan dengan tidak adanya perbedaan pada konsumsi pakan dalam mempengaruhi bobot badan. Berdasarkan hasil penelitian Djaya (2010), batas aman penggunaan tepung MHD maksimal sebanyak 12\%. Soeparno (1994) berpendapat bahwa pakan yang dikonsumsi dan dicerna dengan baik dapat lebih efisien untuk produktifitas ternak. Selain itu, tepung MHD mengandung protease, amilase dan lipase sehingga dapat melengkapi unsur asam amino pakan dan tepung MHD dapat menutupi kekurangan zat nutrisi tertentu dari pakan yang digunakan. Dengan tidak berbeda nyata semua perlakuan yang diberikan, maka pemberian tepung MHD juga tidak berpengaruh terhadap pertambahan bobot badan.

Tidak adanya perbedaan pertambahan bobot badan pada penelitian ini, diduga energi lebih banyak digunakan untuk produksi telur sehingga tidak mempengaruhi bobot badan. Mekanisme hormon pertumbuhan menyebabkan perubahan bobot badan karena sintesis protein. Dalam proses pertumbuhan, kelenjar pituitari anterior dan kelenjar tiroid bekerja secara simultan. Sejalan dengan pernyataan (Glaves and Dewan, 1971) yang menyatakan bahwa semakin tinggi protein maka semakin besar pertambahan bobot hidupnya Menurut Vasilatos (1999). Pertumbuhan merupakan salah satu proses baku dalam kehidupan. Oleh karena itu selsel inti untuk pertumbuhan otot dimulai dari posnatal awal dan berlangsung selama regenerasi jaringan otot yang matang. 
Pertumbuhan dapat didefinisikan sebagai proses pertambahan massa dan selalu diikuti dengan proses perkembangan. Bobot tubuh merupakan akumulasi hasil metabolisme. Hasil metabolisme didukung oleh banyaknya pakan yang dikonsumsi serta optimalisasi penggunaan pakan. Unggas membutuhkan asupan nutrisi yang cukup untuk meningkatkan bobot tubuhnya pada masa pertumbuhan. Salah satunya dengan meningkatkan konsumsi pakan

\section{Pengaruh Perlakuan Terhadap Efisiensi Penggunaan Ransum}

Hasil pengamatan dan perhitungan terhadap rataan. Efisiensi Penggunaan ransum per ekor per hari dari masing-masing perlakuan selama percobaan.

Hasil analisis ragam menunjukkan bahwa pemberian tepung manure hasil degradasi larva lalat hitam pada burung puyuh fase grower tidak memberikan pengaruh yang nyata $(\mathrm{P}>0,05)$ terhadap efisiensi pengunaan ransum.

Hal ini mengambarkan bahwa pemberian tepung MHD sampai dengan level 12\% dalam ransum burung puyuh memberikan pengaruh yang sama terhadap ransum. Tidak berbedanya efisiensi penggunanaan ransum dapat diduga karena konsumsi zat-zat makanan dan penggunaan zat-zat makanan adalah sama, ini didukung oleh peryataan dari Anggrodi (1985) bahwa secara umum efisiensi penggunaan ransum antara lain dipengaruhi oleh konsumsi dan penggunaan zat-zat makanan. Oleh karena konsumsi zat-zat dan penggunaan zat-zat makanan adalah sama berarti hal ini dapat dijelaskan bahwa kemampuan burung puyuh untuk mentrasfer makanan menjadi produk adalah sama. Dengan kata lain bahwa nilai efisiensi dari penggunaan tepung manure hasil degradasi larva lalat hitam level $12 \%$ sebagai pengganti tepung ikan dalam ransum burung puyuh fase grower adalah sama artinya kualitas dari ransum yang digunakan telah seimbang dan cukup sesuai dengan kebutuhan burung puyuh fase grower.

Efisiensi penggunaan energi ditentukan oleh faktor-faktor seperti ketersediaan bahan makanan, genetik, dan faktor-faktor hormon yang mempengaruhi kebutuhan energi tersedia terhadap produksi energi (Djulardi et al., 2006). Moritsu et al. (1997) menyatakan bahwa seperti kadar serat kasar yang tinggi akan menurunkan nilai daya cerna bahan makanan, dapat menurunkan pertambahan bobot badan dan menurunkan efisiensi penggunaan ransum. 


\section{KESIMPULAN}

Berdasarkan hasil analisa dan pembahasan dapat disimpulkan bahwa penggunaan Tepung Manure Hasil Degradasi Larva Lalat Hitam (Hermetia Illucens L) sampai dengan $4 \%$ dapat menggantikan tepung ikan dalam ransum burung puyuh fase grower.

\section{DAFTAR PUSTAKA}

Anggorodi, R.M 1985. Ilmu Makanan Ternak Umum. P.T, Gramedia. Jakarta.

Djaya, M. S. 2010. Pengaruh penggunaan tepung darah dalam ransum terhadap penampilan burung puyuh. Media Sains, 2 (2): 20853548.

Djulardi, A., H. Muis dan S. A. Latif. 2006. Nutrisi Aneka Ternak dan Satwa Harapan. Andalas University Press, Padang.

Gleaves, E.W. dan S. Dewan. 1971, The influence of dietary an environmental factor uponfeed consumption and production respons in laying chicks. Poultry Sci. 50(1): 46-55

Manangkot, H.J. 2014, Black soldier fly larvae manure degradation as fish meal replacer in native chicken ration. Seria Zootehnie 62:139-142.
Moritsu, Y., K.E. Nestor, D.O. Noble, N.B Antony, dan W.C. Bacon., 1997. Divergent selection for boby weight and yolk frecursor in Coturnix coturnix japonica. heterosis in reciprocal crosses between divergently selected lines. Poultry Sci. 76(3): 437-444.

NRC [National Research Council]. 1994. Nutrient Requirement of Poultry National Academy of Science, Washington DC.

North, M. O. dan D.D. Bell. 1990. Commercial Chicken Production manual. $4^{\text {th }}$ Edition. Springer

Rasyaf, M. 1984. Program Linier Untuk Industri Ransum Ternak. Yayasan Kanisius, Yogyakarta.

Schraible, P.J. 1976. Poultry Feed and Nutritition. The avi Publising Company Inc.

Soeparno, 1994. Ilmu dan Teknologi daging. Cetakan kedua. Gadjah Mada University Press. Yogyakarta.

Sudrajat, D., Kardaya dan Puteri. 2002. Performa produksi telur burung puyuh yang diberi ransum mengandung kromium organik. JITV 19(4):257-262.

Steel, R.G.D. dan J.H Torrie, 1994.Prinsip Dan Prosedur Statistika Suatu Pendidikan Giometrik, PT. Gramedia Pustaka Utama. Jakarta.

Sunarno, 2004. Potensi Burung Puyuh. Majalah Poultry indonesia Edisi Februari hal: 61. 
Syariefa. 2011. Ternak Puyuh. Jakarta: Trubus Swadaya.

Vasilatos-Younken, R. 1999. Absence of growth Hormone-Induced Avian Muscle Growth in vivo. Poultry Science. 78(5):759-768 
